\title{
Role of the South in the Development of International Environmental Law
}

\author{
Parvez HASSAN \\ Senior Advocate, Supreme Court of Pakistan \\ hassanandhassan@gmail.com
}

\begin{abstract}
In the post-colonial era, the newly emerging and independent states of Asia and Africa, supported by the developing world in South America, questioned the validity and legitimacy of norms of international law. Those norms were perceived to serve only the interests of the developed Western nations and were alien to the aspirations of the developing countries. International law has evolved over time, with a willingness to accept the viewpoint of new participants in the global process in a variety of contexts. These include the international protection of human rights and international law regarding the permanent sovereignty of nations over their natural wealth and resources. The interests of developing countries have been assimilated, though the extent to which this is done varies. A central message advanced is that the ultimate integrity of international law is the commonality and synthesis of the interests of all states, rich and poor, agricultural and industrial. The continuing contribution of developing countries, through their participation in conferences, negotiation of treaties and soft law texts, adds immeasurable strength to the current state and future development of international environmental law.
\end{abstract}

\section{Keywords}

developing countries - influence of the South - international environmental law international environmental conferences - negotiation of conventions - covenants agreements - human rights and environment - right to development - sustainable development

* This article is based on an address to the 1st IUCN World Congress on Environmental Law, Rio de Janeiro, April 2016.

(C) PARVEZ HASSAN, 2018 | DOI 10.1163/24686042-12340011

This is an open access article distributed under the terms of the prevailing CC-BY-NC license at the time of publication. 


\section{Anglo-European Origins of Public International Law and its Challenge by the Newly-Independent Asian-African States}

This article suggests that one of the most durable strengths of international environmental law is that there was broad participation of the global community in its origins and development from at least the end of World War Two. This contrasts with the challenge, credibly hurled, a half century and more ago, by the newly independent Asian-African states that public international law originated in the practices of the European community and did not reflect the will of the developing, mostly formerly colonized, countries. This tension between the developed and developing countries played out, principally, in the United Nations in the debates leading to the 1960 Declaration on the Granting of Independence to Colonial Countries and Peoples ${ }^{1}$ ('Decolonization Resolution') and the 1962 Resolution on the Permanent Sovereignty over Natural Wealth and Resources ${ }^{2}$ ('Permanent Sovereignty Resolution'). These two Resolutions (the 'Resolutions') empowered the newly-independent countries to participate effectively in the international political and economic orders. They set the stage for, and, in fact, dominated the North-South dialogue on practically all issues before the global community, including the growing international concerns for environmental protection in the early 1970 . Modern international environmental law is generally seen to have emerged with the Stockholm Conference ${ }^{3}$ in 1972 . Coming after the Resolutions, the development, acceptance and ownership of international environmental law benefited from significant participation of the large majority of states, developed and developing, north and south, from the very beginning.

In 1962, R.P. ANAND wrote a penetrating review of the European origins of public international law and how its norms had to meet the challenge of the recently decolonized Asian-African states that had not participated in their

1 Decolonization Resolution UNGA Res 1514 (Xv) 14 December $1960<$ http://www.un.org/en/ decolonization/declaration.shtml $>$ accessed 4 November 2017.

2 Permanent Sovereignty Resolution UNGA Res 1803 (XVII) 14 December $1962<$ http://www .ohchr.org/EN/ProfessionalInterest/Pages/NaturalResources.aspx $>$ accessed 4 November 2017 .

3 The Stockholm Conference generated the Stockholm Declaration that contained a set of 25 principles several of which have become part of customary law and that have been included in the provisions of subsequent multilateral environmental agreements; see Report of the Stockholm Conference on the Human Environment 1972, which contains the Stockholm Declaration, at <http://staging.unep.org/Documents.Multilingual/Default.Print.asp?Docum entID $=97 \&$ ArticleID $=1503 \& \mathrm{l}=\mathrm{en}>$ accessed 2 October 2017 . 
adoption. ${ }^{4}$ He included the Latin American states that had similarly not participated in the development of the corpus of public international law at that time. He observed:

\begin{abstract}
After the Second World War, in 1945, when a second effort was made to establish a universal world order, the whole balance of forces had changed. The United Nations reflects this revolutionary change on the international scene. We have, for the first time in history, a general international organization which, for all practical purposes, is of a worldwide character. With the emergence and participation of Asian-African countries, international society has become a true world society with already more than a hundred members, and some more coming in. ${ }^{5}$
\end{abstract}

He argued that international law was developed over the last four centuries, with consolidation and systematization occurring in the last part of the nineteenth and the beginning of the twentieth century, but that the Asian and African countries were not involved because they had been conquered and colonized. These countries therefore merely served the interests of the metropolitan states and their masters, and were not in a position to contribute to the development of international law. ${ }^{6}$ With respect to Latin American countries, ANAND contended that, having the same cultural, social and religious heritage as the European countries, they were, in several places, able to challenge the present system of international law, citing the Calvo and Drago doctrines ${ }^{7}$ as manifestations of those challenges. ${ }^{8}$ ANAND went on, in 1966 , to reiterate the emerging importance of the Asian-African states in dealing with certain issues of international law in another trail-blazing article, in which he argued that:

During the nineteenth century, as the European countries came to develop their power, however, under the influence of positivism, they

4 RP ANAND, 'Role of the "New" Asian-African Countries in the Present International Legal Order', The American Journal of International Law 56(2) 383-406 (1962).

5 Ibid 384 .

6 Ibid $384-385$.

7 See Amos S HERSHEY 'The Calvo and Drago Doctrines' The American Journal of International Law, 1(1) 26-45 (1907) available at <http://www.repository.law.indiana.edu/cgi/viewcontent. cgi?article $=2959 \&$ context $=$ facpub $>$ accessed 4 November 2017.

8 ANAND (n 4) 389 . 
began to question the legal personality of the Asian States. At the Congress of Vienna in 1815 a few great Powers established an exclusive club in the Concert of Europe and appointed themselves as guardians of the European community and executive directors of its affairs. They assumed the authority to admit new member States or to readmit old members who did not participate in the foundations of this closed club. They claimed to 'issue, or deny, a certificate of birth to States or governments irrespective of their existence. ${ }^{9}$

ANAND noted that 'with the emergence and participation of so many Asian and African States international society has become, for the first time in history, a true world society'. ${ }^{10} \mathrm{He}$ observed that the United Nations is 'where they can make their voices heard and where they have some scope for concerted action, enhances their power and helps them in pursuing their purposes' and that the General Assembly, which he characterised as 'the stronghold of the small countries, is 'where they enjoy complete formal equality with the big Powers and, of course, numerical superiority'.11

Although five Asian States participated in the Hague Peace Conferences, ${ }^{12}$ which number increased to twelve Asian and African countries during the League of Nations period ${ }^{13}$ (except for Japan), none of these countries had any effective voice in international affairs, and Europe continued to lead on the world's stage. It was only after the Second World War, in fact only since 1955, that most of these countries acquired independence and became full-fledged members of international society. More importantly, because of their numerical superiority in the United Nations, they came to acquire an exceptional influence in international affairs. Soon, the criteria of 'civilised nation' as a basis for participation in the community of nations, the meaning of 'civilization as synonymous with the 'Christian-Western civilization', and the notion of 'civilised nation' as corresponding to 'advanced, industrial, commercial nation', were rejected. ${ }^{14}$

9 RP ANAND, 'Attitude of the Asian-African States toward Certain Problems of International Law', International and Comparative Law Quarterly 15 (1), 55-75 (1966).

$10 \quad$ Ibid 55 .

11 Ibid.

12 These conferences took place in 1899 and 1907 and resulted in the Hague Conventions on the Laws of War, Convention (IV) respecting the Laws and Customs of War on Land and its annex: Regulations concerning the Laws and Customs of War on Land. The Hague, 18 October 1907 (36 Stat., 2277, Treaty Series 539).

13 The League of Nations was in existence from 1920 to 1946, when it was formally dissolved.

14 ANAND (n 9) 6 o. 
Once independent, and having gained equality with all other nations in the General Assembly, the Asian-African states set out to question the 'colonial' orientation of international law. The socialist bloc, fuelled by the Cold War, ${ }^{15}$ became an important ally in this new challenge. However, these protests against some parts of international law were neither confined to the Asian-African States, nor were they the first to demand the modification of their legal status. ANAND noted that 'most of the underdeveloped states of Asia, Africa, Latin America and even those of Europe' insisted that international law should be more responsive to their needs. He argued that the Calvo and Drago doctrines that emerged from the Latin American countries, for example, challenged the traditional international law as against the interests of debtor states. ${ }^{16}$

After the brief historical analysis of the influence of developing counties in the emergence of international law in section 2, this article narrows its focus in section 3 to show that the field of international environmental law in the modern era has been and continues to be shaped by the involvement of governments and international non-government organisations representing the South in major global conferences on the environment and in the drafting of many of the fundamental resolutions, instruments and declarations.

The adoption of the United Nations Charter in $1945^{17}$ and the Universal Declaration of Human Rights in $1948^{18}$ had generated hopes and euphoria for a new international order anchored in the sovereign equality of states and the respect for fundamental human rights and the dignity and worth of the human person. The newly independent members of the international community started clamouring for a voice and recognition and the United Nations General Assembly became a natural forum for such efforts. The adoption of the Decolonization Resolution in 1960 and the Permanent Sovereignty Resolution in 1962, both immensely facilitated by the contemporary Cold War dynamics, were to imprint the future work and the dialogue at all the fora of the United Nations.

\footnotetext{
15 'Cold War' in this context refers to 'the ideological conflict between the U.s. and the U.S.S.R. during the second half of the 2oth century' (Merriam-Webster Dictionary).

16 ANAND (n 9), 66-67.

17 Charter of the United Nations 24 October 19451 UNTS xvi.

18 Universal Declaration of Human Rights 1948, UNGA 217 A (III).
} 
2.1 The Decolonization Resolution (196o)

The Preamble to the Decolonization Resolution ${ }^{19}$ declared that the 'subjection of peoples to alien subjugation, domination and exploitation constitutes a denial of fundamental human rights, is contrary to the Charter of the United Nations and is an impediment to the promotion of world peace and co-operation' and '[a]ll peoples have the right to self-determination; by virtue of that right they freely determine their political status and freely pursue their economic, social and cultural development'. It recognized that 'colonialism prevents the development of international economic cooperation, impedes the social, cultural and economic development of dependent peoples and militates against the United Nations ideal of universal peace'.

Further, the Decolonization Resolution proclaimed that immediate steps shall be taken in 'all ... territories which have not yet attained independence, to transfer all powers to the peoples of those territories, without any conditions or reservations, in accordance with their freely expressed will and desire, without any distinction as to race, creed or colour, in order to enable them to enjoy complete independence and freedom.'20 Importantly, it was recognized from the outset that political independence is inextricably tied to the right of each nation to its natural wealth and resources. It was important to express in unequivocal terms that 'peoples may, for their own ends, freely dispose of their natural wealth and resources without prejudice to any obligations arising out of international economic co-operation, based upon the principle of mutual benefit, and international law'.21

The die was thus cast for an emerging role of the newly independent AsianAfrican countries in the international legal order in which they sought redress against colonial imperialism on the basis of equality, equity and justice.

\subsection{The Permanent Sovereignty Resolution (1962)}

The Resolution on Permanent Sovereignty ${ }^{22}$ followed logically from the Decolonization Resolution. The validity of the traditional international law of responsibility of states for injuries to aliens had been questioned by many of the newly independent countries. The socialist countries had taken the lead to emphasize the change in the world context which necessitated revitalization and revision of rules of international law. The change referred to was the emergence of a new socialist system and the attainment of independence by

\footnotetext{
19 Decolonization Resolution ( $\mathrm{n}_{1}$ ).

20 Ibid Para 5.

21 Ibid Preamble.

22 Permanent Sovereignty Resolution (n 2) Preamble.
} 
some forty countries after World War Two. These sentiments were reflected in the report of the International Law Commission, on the question of State Responsibility, quoting Soviet representative Grigory TUNKIN:

It was not only the geography of international law that had changed ... but its economic foundation. Present-day international law could not be a system of legal rules imposed by States belonging to one economic system on States belonging to another; world-wide international law could not contain rules which were incompatible with the principles of one of the two main economic systems.... the countries on whom international law had formerly been imposed in order to facilitate their exploitation were now called upon to partake in its formulation. The further development of international law should be on a basis of peaceful competition and collaboration between all States, irrespective of their political, economic or social systems. International law was one means to ensure their peaceful co-existence. ${ }^{23}$

Emphasizing the same aspect, a Latin American diplomat, Padillo NERVO, referred to the fact that the vast majority of the states had taken no part in the creation of many institutions of international law which were consolidated and systematized in the nineteenth century. ${ }^{24}$

As early as 1958, the General Assembly had established the Commission on Permanent Sovereignty over Natural Resources to 'conduct a full survey of the status of permanent sovereignty over natural wealth and resources as a basic constituent of the right to self-determination, with recommendations, where necessary, for its strengthening, and decided further that, in the conduct of the full survey of the status of the permanent sovereignty of peoples and nations over their natural wealth and resources, due regard should be paid to the rights and duties of States under international law and to the importance of encouraging international co-operation in the economic development of developing countries. ${ }^{25}$

In 1960, the General Assembly recommended 'that the sovereign right of every State to dispose of its wealth and its natural resources should be

23 State responsibility (A/CN.4/106) Summarised from 1957 Year Book of the International Law Commission Vol 1, 165, para $27<\mathrm{http} / /$ legal.un.org/ilc/publications/yearbooks/ english/ilc_1957_vı.pdf> accessed 7 November 2017; see also René PROVOST (ed) State Responsibility in International Law (Routledge 2016).

241957 Year Book of the International Law Commission, (n 23) 155 para 46.

25 Permanent Sovereignty Resolution (n 2) Preamble. 
respected. ${ }^{26}$ In 1962, the Permanent Sovereignty Resolution ${ }^{27}$ considered that any measure 'must be based on the recognition of the inalienable right of all States freely to dispose of their natural wealth and resources in accordance with their national interests, and on respect for the economic independence of States' and declared that:

1. The right of peoples and nations to permanent sovereignty over their natural wealth and resources must be exercised in the interest of their national development and of the well-being of the people of the State concerned.

2. The exploration, development and disposition of such resources, as well as the import of the foreign capital required for these purposes, should be in conformity with the rules and conditions which the peoples and nations freely consider to be necessary or desirable with regard to the authorization, restriction or prohibition of such activities.

5. The free and beneficial exercise of the sovereignty of peoples and nations over their natural resources must be furthered by the mutual respect of States based on their sovereign equality.

6. International co-operation for the economic development of developing countries, whether in the form of public or private capital investments, exchange of goods and services, technical assistance, or exchange of scientific information, shall be such as to further their independent national development and shall be based upon respect for their sovereignty over their natural wealth and resources.

7. Violation of the rights of peoples and nations to sovereignty over their natural wealth and resources is contrary to the spirit and principles of the Charter of the United Nations and hinders the development of international co-operation and the maintenance of peace. ${ }^{28}$

These statements provided robust endorsement of the demand by developing states to assert their independence from their former colonial masters in terms of freedom of decision-making concerning their natural resources. But they also provided an important basis for the building of an international regime of environmental law in which those states came to play a vital part.

26 UNGa Res 1515 (xv) Concerted Action for Economic Development of Less Developed Countries, 15 December 1960, Preamble.

27 Permanent Sovereignty Resolution (n 2).

28 Ibid Preamble. 


\section{The Development of International Environmental Law ${ }^{29}$}

\subsection{Stockholm Conference 1972}

While much of what was accomplished at the United Nations Conference on the Human Environment at Stockholm in 1972 had its beginnings in the earlier experiences and policies of several countries, this Conference is generally perceived as the catalyst that focused international attention and action on the importance of the environment in the global system. There was a concerted effort made to ensure that developing countries could participate in the conference. ${ }^{30}$ Of the 113 countries invited, over 80 would have been regarded as 'developing' at the time. ${ }^{31}$

The inspiring Stockholm Declaration on the Human Environment adopted there ${ }^{32}$ proclaimed that environmental concerns transcend national

29 Some parts of this section have drawn from the author's presentation at the 1993 Annual Meeting of the American Society of International Law, Toward an International Covenant on Environment and Development, American Society of International Law Proceedings 513-522 (1993).

30 The Un Secretary General issued 'Measures Designed to Secure Developing Countries' Participation'; see GAOR, 24th Session, Fifth Committee, 1327th Meeting, 13 November 1969, 215, and United Nations Conference on the Human Environment, The North-South Debate on International Environmental Issues, at <http://shodhganga.inflibnet.ac.in/ bitstream/10603/18052/9/o9_chapter\%203.pdf > accessed 2 October 2017.

31 Representatives of the following 113 States were invited: Afghanistan, Algeria, Argentina, Australia, Austria, Bahrein, Bangladesh, Belgium, Bolivia, Botswana, Brazil, Burundi, Cameroon, Canada, Central African Republic, Ceylon (now Sri Lanka), Chad, Chile, China, Colombia, Congo, Costa Rica, Cyprus, (then) Dahomey (now Benin), Denmark, Dominican Republic, Ecuador, Egypt, El Salvador, Ethiopia, (then) Federal Republic of Germany, Fiji, Finland, France, Gabon, Ghana, Greece, Guatemala, Guinea, Guyana, Haiti, Holy See, Honduras, Iceland, India, Indonesia, Iran, Iraq, Ireland, Israel, Italy, Ivory Coast, Jamaica, Japan, Jordan, Kenya, Kuwait, Lebanon, Lesotho, Liberia, Libyan Arab Republic, Liechtenstein, Luxembourg, Madagascar, Malawi, Malaysia, Malta, Mauritania, Mauritius, Mexico, Monaco, Morocco, Nepal, Netherlands, New Zealand, Nicaragua, Niger, Nigeria, Norway, Pakistan, Panama, Peru, Philippines, Portugal, Republic of Korea, Republic of Viet-Nam, Romania, San Marino, Senegal, Singapore, South Africa, Spain, Sudan, Swaziland, Sweden, Switzerland, Syrian Arab Republic, Thailand, Togo, Trinidad and Tobago, Tunisia, Turkey, Uganda, United Arab Emirates, United Kingdom of Great Britain and Northern Ireland, United Republic of Tanzania, United States of America, Uruguay, Venezuela, Yemen, (then) Yugoslavia, Zaire, Zambia: Report of the United Nations Conference on the Human Environment Stockholm, 5-16 June 197, at <http://www.un-documents.net/aconf48-14r1.pdf> accessed 2 October 2017; and United Nations Conference on the Human Environment, UNGA $285^{\circ}$ (XXVI). 
boundaries. Almost a quarter of a century earlier, in 1948, the UN General Assembly had proclaimed an equally visionary Universal Declaration of Human Rights that brought the protection of human rights within the legitimate concern of the international community. The Stockholm Declaration had a similar impact in the field of the environment. ${ }^{33}$

The Stockholm Declaration recognized many concepts that would guide the evolution of international environmental law. Four are briefly considered here:

(1) At the outset, the importance of development was highlighted. Thus, environment was perceived as not the only conduit for attaining an appropriate quality of life, recognizing that it is through development, when properly planned, that the quality of life is ensured (Principles 2, 12, 13, 14, 15 and 17 on planning). The essential interdependence between environment and development was thus acknowledged (Preamble, Principles 2, 4 and 8 on economic and social development).

(2) The need to defend and improve the human environment for present and future generations, recognized as an imperative goal for humankind for present and future generations, was highlighted (Preamble, and Principles 1 and 2).

(3) Equity was sought in the international economic system, and the need for international cooperation to raise resources to assist the developing countries was duly emphasized. The Declaration went even further, stressing the obligation of industrialised countries to make efforts to reduce the economic gap between themselves and the developing countries (Preamble). These obligations specifically encompassed transfer of financial and technological assistance (Principle 9), fair pricing for the commodities and raw materials of the developing countries in the international system (Principle 10), resource allocation and international technical and financial assistance to developing countries (Principle 12) and free flow of technology and experience from the developed to the developing countries on terms 'which would encourage their wide dissemination without constituting an economic burden on the developing countries' (Principle 20).

(4) Perhaps the most important principle that emerged at Stockholm was Principle 21, proclaiming, lest Stockholm was to be perceived as anti-development, the sovereign right of all states to 'exploit their own resources

33 See generally Alexandre KISS and Parvez HASSAN, 'General Environmental Concerns', in Peter H. SAND (ed) The Effectiveness of International Environmental Agreements, Cambridge University Press (1993) at $28-58$. 
pursuant to their own environmental policies'. Importantly, Principle 21 also sought to 'codify' the international law principle that emerged in cases such as Trail Smelter ${ }^{34}$ and Island of Palmas, ${ }^{35}$ whereby states are held responsible for activities carried out 'within their jurisdiction or control' that 'cause damage to the environment of other States or of areas beyond the limits of national jurisdiction.'

It is appropriate here to clarify the 'sovereign right to develop' principle incorporated in Principle 21. History and the Southern mind-set explain its inclusion. Exactly a decade before the Stockholm Declaration, the then newly independent Asian-African countries, with the pivotal support of the Soviet Union, had carved out the United Nations Resolution on Permanent Sovereignty referred to above. The drafting history of the Permanent Sovereignty Resolution indicates the strength of feeling generated between the emerging South and the North (industrialized nations) over who owns and controls the natural resource base of a country. ${ }^{36}$ Statistics galore were marshalled by the South to demonstrate how countries in the North, as colonialists, had reaped and raped the natural resources of former colonies. It was against this background that the developing countries felt the need to fight for the acknowledgment of their right over their natural resources. So important was this to the South that it carried its mistrust of the developed nations, in 1966, into Articles 1(2) of both the International Covenant on Economic, Social and Cultural Rights ${ }^{37}$ and the International Covenant on Civil and Political Rights ${ }^{38}$ to acknowledge that all 'peoples may, for their own needs, freely dispose of their natural wealth and resources without prejudice to any obligations arising out of international economic cooperation, based on the principle of mutual benefit, and international law'. This was included within the Articles dealing with the right to

34 Trail Smelter Arbitration (U.S.A. v. Canada) 3 UNRAA, p. 1905.

35 Island of Palmas Case (U.S.A. v. Netherlands) 2 UNRAA, p. 281; see also the Corfu Channel Case, ICJ Rep. 1949, 4.

36 See, generally, 'Introductory Note' and 'Procedural History', United Nations AudioVisual Library of International Law <http://legal.un.org/avl/ha/ga_1803/ga_1803.html>; see also Ricardo PEREIRA and Orla GOUGH 'Permanent Sovereignty over Natural Resources in the 21st Century: Natural Resource Governance and the Right to SelfDetermination of Indigenous Peoples under International Law' (2013) 14(2) Melb. J. Int'l L 452,455 .

37 International Covenant on Economic, Social and Cultural Rights 1966, 993 UNTS 3, entry into force 3 January 1976.

38 International Covenant on Civil and Political Rights 1966, 999 UNTS 171 entry into force 23 March 1976. 
self-determination. Having accomplished this, the South was not about to throw away this gain in the contemporary concerns of environmental protection as expressed in the Stockholm Declaration in the 1970s. ${ }^{39}$

Stockholm, therefore, represented an appropriate synthesis of the emerging dichotomy between the interests of the developed world and the developing countries. It was the first global conference on the environment, which saw the genesis of modern international environmental law and its emerging principles. It was remarkable also for the wide participation of the newly independent Asian-African states that gained the opportunity from the very beginning to shape those principles. In fact, the representation from the South was impressive in the leadership of the Conference. Prime Minister Indira GANDHI of India, for example, captured international attention as the most prominent face for the Asian, African and Latin American countries, ${ }^{40}$

\subsection{World Charter for Nature 1982}

A decade after Stockholm, on the initiative of the International Union for Conservation of Nature and Natural Resources (IUCN) - the UN General Assembly adopted the World Charter for Nature. ${ }^{41}$ Perhaps overlooked is the fact that the seed of the World Charter for Nature was sown in the South. It is to be found in the inaugural address of General MOBUTU Seso Seko, President of

39 Some of this history is traced in Sumuda APATTU 'The Significance of International Environmental Law Principles in Reinforcing or Dismantling the North-South Divide' esp. '2.1, Permanent sovereignty over natural resources', in ALAM et al (eds) International Environmental Law and the Global South (Cambridge 2015) 80-82; she observes at 80 that 'One of the early examples of Southern countries influence over natural resources in the global arena is the adoption of the permanent sovereignty (PNSR) principle.'

See Indira GANDHI's Speech at the Stockholm Conference in 1972 'Man and Environment', Plenary Session of United Nations Conference on Human Environment, Stockholm 14 June $1972<$ http://lasulawsenvironmental.blogspot.com/2012/07/indira-gandhisspeech-at-stockholm.html> accessed 4 November 2017; Karin MICKELSON, 'The Stockholm Conference and the South-North Divide in International Environmental Law and Policy' in ALAM (n 39), 115, states that Mrs GANDHI's speech 'was regarded by many as encapsulating the difference in perception between South and North.'

41 World Charter for Nature, G.A. Res. 7, 36 U.N. GAOR Supp. (No. 51) 17, Doc. A/51 (1982) <http://www.un.org/documents/ga/res/37/a37roo7.htm> accessed 2 October 2017. The United States was the only country that voted against the World Charter, with a 111 to 1 vote; referred to in Nic BELOTT, 'Us World Charter for Nature Passes-United States is the Only Country Opposing' October 28, 2016, <https://www.ecodefenseradio.org/2016/10/28/ un-world-charter-for-nature-passes/> accessed 2 October 2017. 
Zaire, at the twelfth General Assembly of the IUCN in Kinshasa in September $1975 .{ }^{42}$ MOBUTU held out both a challenge and an offer:

The seas, the oceans the upper atmosphere belong to the human community.... One cannot freely overuse [such] international resources. People of good will ... are looking to you for positive results from this Assembly.... That is why, if I had any advice for you, I would suggest the establishment of a Charter of Nature.... Insofar as Zaire is concerned, we are ready to help you succeed.... ${ }^{43}$

The IUCN took up the challenge through its World Commission on Environmental Law (as it is now known), and set up a task force which, using the 1948 Un Declaration of Human Rights as a model, developed the first draft of the World Charter. Consistent with the Stockholm Declaration, the World Charter also emphasizes sovereignty of states over their natural resources (para 22). While the Charter postulates general principles for implementation and cooperation among the states, it is weak on the requirement by the South that a fair international economic system is essential to the attainment of its goals and principles.

\subsection{Rio Conference 1992}

The Stockholm Declaration had identified the North-South divide over environmental matters. As noted above, World Charter was strong on general principles but feeble on emphasizing the South's right to development. The discussions in the various Preparatory Committees (Prepcoms) of the UN Conference on Environment and Development (UNCED), also known as the Rio Earth Summit, reflected these conflicts between developed and developing countries. Each issue and each proposal that went into the preparatory work ${ }^{44}$ for the Rio Earth Summit was overshadowed by the difference of perceptions

42 See further, Harold W. WOOD, Jr 'The United Nations World Charter for Nature: The Developing Nations' Initiative to Establish Protections for the Environment' 12 Ecology L.Q. 977 (1985) at 978 <http://scholarship.law.berkeley.edu/cgi/viewcontent .cgi? article $=1268 \&$ context $=$ elq $>$ accessed 2 October 2017.

43 Quoted in Wolfgang E. BURHENNE \& William A. IRWIN. The World Charter for Nature 14 (IUCN 1986).

44 The Proceedings of the Rio Conference and the Prepcoms were compiled in Nicholas A. ROBINSON, Parvez HASSAN and Françoise BURHENNE-GUILMIN, Agenda 21 and the UNCED Proceedings (Oceana Publications, 1992). 
between the North and the South. ${ }^{45}$ The number of governments involved had increased markedly since Stockholm, with a much greater emphasis on particpation from the non-government sector. ${ }^{46}$

Even the basic motives behind the North's global agenda on environment and development was suspect in the South. The South generally believed that these initiatives were clever ploys by the North to exercise control over the development of the South. The South, time and again in the Prepcoms, argued that the chief villain in the overall global degradation was the industrial North.

Reminiscent of the debates in the General Assembly before the UN Declaration on Permanent Sovereignty, the delegates of the developing countries tabled statistics to show that it was the North that had brought about the critical environmental hazards of the present times. Highlighting the wasteful consumption patterns of the North, it was pointed out, for example, that 80 percent of the world's resources are being utilized by the 20 percent of the world's population that lives in the industrialized states. The world GDP increased by US $\$ 520$ trillion during $1972-1992$. Only 15 percent of this increase accrued to developing countries; 70 percent went to the already rich countries. Mention was also made of the annual flow of more than US $\$ 50$ billion from the South to the North. It was persuasively contended that the crippling debt burden of the South, constraints on the transfer of technology, the trade barriers, discriminatory subsidies and other inequitable economic policies of the North handicapped the ability of the Southern countries to achieve their developmental potential. In the final analysis, the arguments continued, it was exceedingly important that financing mechanisms be put in place to alleviate poverty levels in the South. ${ }^{47}$ So overwhelming was this quest by countries of the South for equity in the international system that, at one stage, the success or failure of Rio looked as if it would hang on the response of the North to this critical demand.

UNCED saw the emergence of a third category of interests beyond the political blocks of North and South. This was 'countries in economic transition', comprising the former socialist countries.

46 The Rio Earth Summit attracted 172 governments, 108 represented at level of heads of State or Government, around 2,400 representatives of non-governmental organizations, and a total of 17,000 people attended the parallel NGO Forum, with many more involved in preparatory meetings in their own countries; see <http://www.un.org/geninfo/bp/enviro .html $>$ An overwhelming number of the countries and participants were from the South.

47 See generally Sir Shridath RAMPHAL, Our Country, The Planet (Island Press 1992). This is one of the most eloquent expositions of North-South issues that framed the international debates in the 1990s; a more contemporary set of analyses is found in ALAM et al (eds) (n 39). 
In spite of prophecies of doom, Rio demonstrated the inherent resilience of the international system whereby views as conflicting and opposed as those that emerged during the preparatory process and at Rio were synthesized in the global partnership and alliance that was proclaimed in the Rio Declaration, ${ }^{48}$ Agenda 21, and the opening for signature of the Conventions on Biological Diversity and Climate Change. ${ }^{49}$ The adoption of the Non-Legally Binding Forest Principles, however unsatisfactory to the North, also contributed to the perception of the Rio Earth Summit's success.

The Rio Declaration, with its 27 Principles, represented the best compromise statement on environment and development under the circumstances. Its essential elements are:

1 Acknowledgment of the interdependence of environment and development (Principles 1 and 2).

2 Recognition of the needs of both present and future generations (Principle 3).

3 Establishment of poverty alleviation as an indispensable instrument for sustainable development, and the stipulation that this must be handled among all states and all peoples on a cooperative basis (Principle 5).

4 Agreement that special needs of developing countries shall have special priority (Principle 6).

5 Recognition of the need for an equitable international economic system with fairer prices and trade policies (Principle 12).

The Rio Declaration 1992 moved beyond the Stockholm Declaration 1972 almost to the extent of requiring 'affirmative action' in favour of the developing countries. This obligation was further reinforced in the adoption of the ambitious and comprehensive Agenda 21, which calls for special responsibilities of the developed countries to finance and support its various components. ${ }^{50}$

48 Rio Declaration on Environment and Development <http://www.un.org/documents/ga/ confi51/aconfi5126-1annexı.htm> accessed 4 November 2017.

49 For a contrary view, see Kenny BRUNO, The Corporate Capture of the Earth Summit <http://www.multinationalmonitor.org/hyper/issues/1992/07/mmo792_07.html> accessed 2 October 2017.

$5^{0}$ United Nations Conference on Environment and Development Rio de Janeiro, Brazil, 3 to 14 June 1992, Agenda 21 <https://sustainabledevelopment.un.org/content/documents/Agenda21.pdf> accessed 2 October 2017; see generally, Chapter 33, 'Financial Resources and Mechanisms'. Articles 20 and 21 of the Convention on Biological Diversity are also good examples of the consensus in the international community that the developed countries have special obligations with respect to financing environmental efforts 
The journey to Rio 1992 involved a preparatory process almost unprecedented in the history of international relations. Did UNCED succeed or was it a failure? What lessons were learned there? Undoubtedly, there were both triumphs and failures. The final perception will, however, depend on whether one sees the bottle as half-full or half-empty. The preference of the author is to see the bottle as half-full. The world community got a Convention on Climate Change and a Convention on Biodiversity, however modest their reach when compared with the original expectations. There was also a better appreciation of the respective positions of the developed and the developing countries on the conservation and exploitation of national forestry resources. A comprehensive Agenda 21 guided this planet's future into the next millennium. Of fundamental importance to all these was the Rio Declaration on Environment and Development and the events and documents which have flowed from it since $1992 .{ }^{51}$

We can anticipate that history will judge the entire UNCED process favourably. For the first time, it demonstrated that environmental and developmental concerns spanning North and South, East and West have contributed to an understanding that we are truly an interdependent world. The process itself was robust, allowing free debate and open dialogue. It was democratic in that it enabled universal participation. The welcome and pioneering accesshowever limited - offered to the non-governmental organizations made it the most transparent negotiating process to that time. The discussions involved issues vital to the viability of the Earth. The polarization and acrimony between the North and the South may have discouraged some, but the fact that the process enabled a frank and candid dialogue was a vital contribution to the increased transparency of all subsequent global environmental debates.

In a way, Rio 1992 was a triumph for the imprint of the South on the global environmental agenda. India, through its Prime Minister Indira GANDHI, had lent much visibility to the South at Stockholm in 1972. Rio 1992 provided an

in the developing countries. The Tokyo Declaration on Financing Global Environment and Development, reprinted in 22 Environmental Policy and Law (265-66) (1992), is yet another typical statement of such obligations of the developed countries.

51 The most significant progress in recent years is manifested in the Rio+2o Conference on Sustainable Development and the agreement of the 2015 UN document "Transforming our World: the 2030 Agenda for Sustainable Development” <https://sustainabledevelopment.un.org/post2015/transformingourworld> accessed 2 October 2017; see further below. 
excellent opportunity for Pakistan's leadership as the Chair of the Group of $77^{52}$ to lead the South. Ambassador Tommy KOH from Singapore, who chaired important meetings, including the one that adopted the Rio Declaration on the Environment and Development, emerged as an important global leader on sustainable development. ${ }^{53}$

The North-South divide surfaces whenever international summitry is involved. Rio 1992 was no exception. The North, at Rio, was led, among others, by the U.S., Germany, the U.K. and Japan. For the South, this leadership fell to Pakistan. Pakistan, as the Chair of the Group of 77 , well grasped this opportunity to provide robust and respected leadership on complex global environmental issues. China invariably supported $G_{77}$ positions and, as a result, when Pakistan spoke at Rio, it represented the voice of a substantial majority of the world's population.

\subsection{IUCN Draft Covenant on Environment and Development (1995)}

The present body of relevant international instruments concerning the environment contains the seeds of universally recognized principles of international environmental law. This was at first particularly evident in procedural matters related to transboundary environmental interventions, such as requirements for prior notification and consultation between the states concerned. It has since become visible for a growing number of substantive issues. These include obligations to refrain from harming the environment of other states and areas outside national jurisdiction, ${ }^{54}$ to carry out environmental impact assessment, to cooperate, and to conserve both the environment and natural resources for the benefit of present and future generations. These and more are particularly recognized in the milestone documents-the Stockholm Declaration, the World Charter and the Rio Declaration discussed above. The emergence of these 'soft' environmental law documents and associated principles was seen to provide the foundation for a new global convention.

52 The Group of 77 was originally founded in 1964 at the United Nations as a coalition of developing countries ' to articulate and promote their collective economic interests and enhance their joint negotiating capacity on all major international economic issues within the United Nations system, and promote South-South cooperation for development.' The number of countries has now grown to 134; see <http://www.g77.org/doc/> accessed 4 November 2017.

53 See Tommy KOH, The Tommy Koh Reader 'The Earth Summit's Negotiating Process', (World Scientific 2013), 483 .

54 Principle 21 of the Stockholm Declaration, (n 3 ) and Principle 2 of the Rio Declaration (n 48). 
In 1988, the IUCN General Assembly ${ }^{55}$ approved a resolution mandating that the IUCN World Commission on Environmental Law prepare a global instrument embodying general environmental legal principles. The 1987 report of the World Commission on Environment and Development (WCED) had underlined the need for such a global instrument, and its Legal Experts Working Group had prepared a corresponding first set of principles. ${ }^{56}$ Since the late 1980's, the IUCN World Commission on Environmental Law has been engaged in the elaboration of a blueprint for such an instrument and has prepared successive drafts of a proposed International Covenant on Environment and Development. Ad hoc Working Groups were constituted by the IUCN World Commission on Environmental Law to progress this. Many of its members were experts who had already participated in the elaboration of the World Charter for Nature and other international environmental law instruments. The IUCN Draft was designated 'Covenant' in order to reflect its similarity of character to the 1966 United Nations International Covenants on Human Rights. ${ }^{57}$

In 2015, the IUCN World Commission on Environmental Law, with the cooperation of the International Council of Environmental Law, produced a fifth edition with a detailed commentary on each Article. ${ }^{58}$ It is hoped that governments will use this draft as a basis for the negotiation of a comprehensive global covenant on environment and development.

The 2015 IUCN draft has 83 Articles, crafted out of existing international environmental declarations and other legal instruments. A particular orientation of the Working Groups was to pick up where the Rio Declaration left off, even attempting to include in their membership the principal players in the

$55 \quad$ Now known as the World Conservation Congress.

56 Annex to Our Common Future (Oxford, 1987).

57 See Covenants (n 37 and $\mathrm{n}_{38}$ ).

58 The Commentary was prepared principally by Professor Dinah SHELTON, George Washington University Law School. See IUCN's Draft International Covenant on Environment and Development, at <https://portals.iucn.org/library/sites/library/files/documents/EPLP-031-rev4.pdf > accossed 18 November 2017. Wolfgang BURHENNE, as the first Chair of the World Commission on Environmental Law, had initiated the process of drafting the Covenant; the author participated from its inception to its launch at the United Nations in 1995, and has continued his engagement with it to the current edition. For background on the Draft Covenant, see Parvez HASSAN, 'The IUCN Draft International Covenant on Environment and Development: Background and Prospects', in A. KISS and F. BURHENNE-GUILMIN (eds), A Law for the Environment: Essays in Honour of Wolfgang E. Burhenne, 39-42 (IUCN 1994); see also B. LAUSCHE, Weaving a Web of Environmental Law (Erich Schmidt, Berlin 2008) <https://portals.iucn.org/library/sites/library/files/documents/ 2008-020.pdf $>$ accessed 2 October 2017. 
Rio and post-Rio processes. The IUCN Draft declares the fundamental principle that the global environment is a common concern of humanity (Article 3). It contains provisions not only on the rights and duties of states (Article 14) but also of individuals (Article 15). There are detailed obligations on states with respect to their natural resources in Articles 20-28 and on transboundary environmental effects (Article 41). There are provisions on the precautionary principle (Article 7), intergenerational equity (Article 5), environmental impact assessment (Article 46), education, training and public awareness (Article 54), and military and hostile activities (Article 40). Also covered are issues such as poverty eradication (Articles 12 and 35), the sovereign right to development (Articles 11), trade and environment (Article 38), development and transfer of technology (Articles 51) and financial mechanisms (Articles 55 and 56 ).

The experience in the drafting of the IUCN Draft Covenant was no different than the North-South divide in other international fora. The drafting group included effective representation of members from the South, and appropriately reflected developing country concerns, including the introduction in the Covenant of provisions on waste trade (Article 32), the need to regulate the activities of transnational economic entities (Article 39), and the strengthening of the clauses on technology (Article 51) and transfer of resources (Article 56).

\subsection{The Earth Charter (200o)}

The Earth Charter ${ }^{59}$ is another important soft law document that has influenced the development of international environmental law. ${ }^{60}$ The Charter, now translated into over 50 languages ${ }^{61}$ is an inspirational statement of lofty concepts that builds on the essential human freedoms of expression, worship, dignity and security and adds the crucial freedom to live in a world in harmony with nature. It provides a richness of content that is impressive in its sheer breadth, with four foundational principles: Respect and Care for the Community of Life, Ecological Integrity, Social and Economic Justice, and

59 See 'Earth Charter Initiative', at <http://earthcharter.org/> accessed 2 October 2017.

6o The author was privileged to take part in the drafting and launch of the Earth Charter in The Hague in 2000; see Parvez HASSAN, 'Earth Charter: The Journey from The Hague 2000', 2002 Pakistan Law Journal (Magazine), at 1-4; Parvez HASSAN 'Earth Charter: An Ethical Lodestar and Moral Force', in P. CORCORAN, M. VILELA and A. ROERINK (eds), The Earth Charter in Action: Toward a Sustainable World, 29-31 (KIT Publishers, Amsterdam 2005).

61 See Earth Chater, at <http://earthcharter.org/virtual-library2/the-earth-charter-text/>accessed 2 October 2017 . 
Democracy, Non-Violence and Peace, which are in turn supported by several subsidiary principles.

In sum, the Earth Charter provides a compelling recognition of respect for diverse traditions. Its preamble states:

We stand at a critical moment in Earth's history, a time when humanity must choose its future. As the world becomes increasingly interdependent and fragile, the future at once holds great peril and great promise. To move forward we must recognize that in the midst of a magnificent diversity of cultures and life forms we are one human family and one Earth community with a common destiny. We must join together to bring forth a sustainable global society founded on respect for nature, universal human rights, economic justice, and a culture of peace. Towards this end, it is imperative that we, the peoples of Earth, declare our responsibility to one another, to the greater community of life, and to future generations.

To achieve this ambitious task, the Charter 'draws on the path-breaking work done in the field of environmental and sustainable development ethics over the past fifty years ... [it] has also been developed in the light of the practical experience and insights of those groups that have successfully pursued sustainable ways of living and working'. ${ }^{62}$ The Charter urges the world community to renew its commitment to the United Nations, fulfil its obligations under existing international agreements, and to assist the implementation of its principles with an international legally binding instrument. This last commitment relates to the emergence of the Draft Covenant mentioned above becoming a binding convention.

\subsection{Johannesburg (2002)}

The World Summit on Sustainable Development (WSSD) that took place in Johannesburg in 2002 continued the legacies of Stockholm and Rio. The preparatory processes leading to the wssD had highlighted the gains at Stockholm and Rio. The Stockholm Declaration and the Rio Declaration were already considered as bench-marks for the conduct of states and societies for sustainable development. Participation from developing country governments was again very strong. ${ }^{63}$ The wSSD highlighted the need to 'walk the talk' in terms

62 Earth Charter International Secretariat, Earth Charter Briefing Book, San José, Costa Rica, 2000.

63 See Report of the Credentials Committee, 29 August 2002, World Summit on Sustainable Development, A/CONF.199/15 <http://www.un.org/ga/search/view_doc.asp?symbol=A/ CONF.199/15\&Lang=E $>$ accessed 4 November 2017. 
of identifying timelines for action. A Plan of Implementation prioritized five areas: water, energy, health, agriculture and biodiversity (known as 'WEHAB') as a part of the overarching goal of poverty alleviation. ${ }^{64}$

The Political Declaration, entitled the Johannesburg Commitment on Sustainable Development, tabled on behalf of President MBEKI of South Africa, reaffirmed the continuation of the Rio legacy and principles and pledged 'from this Continent, the Cradle of Humanity, our responsibility to one another, to the greater community of life and to our children'. In its operative part, under the heading 'Making it Happen', it added: 'We commit ourselves to act together, united by a common determination to save our planet, promote human development and achieve universal prosperity and peace'. The subsequent wssD Report, adapted from the Political Declaration, once again emphasized the concerns of the South:

We welcome the focus of the Johannesburg Summit on the indivisibility of human dignity and are resolved, through decisions on targets, timetables and partnerships, to speedily increase access to such basic requirements as clean water, sanitation, adequate shelter, energy, health care, food security and the protection of biodiversity. At the same time, we will work together to help one another gain access to financial resources, benefit from the opening of markets, ensure capacity-building, use modern technology to bring about development and make sure that there is technology transfer, human resource development, education and training to banish underdevelopment forever. ${ }^{65}$

\section{7 $\quad$ Rio $+20(2012)$}

The United Nations Conference on Sustainable Development in Rio de Janeiro in 2012 (Rio +20) was once again a very significant gathering of governmental, NGO and private sector representatives with a wide involvement of developing countries. ${ }^{66}$ It adopted the historic document 'The Future We Want'. This document is remarkable for the endorsement of all the soft law documents

64 See also Hans Christian BUGGE and Lawrence WATTERS, 'A Perspective on Sustainable Development after Johannesburg on the Fifteenth Anniversary of Our Common Future' 15 Georgetown Environmental Law Review 359 (2003).

65 Reportofthe WorldSummiton Sustainable Development, Johannesburg, South Africa, August $2002<$ http://www.un.org/ga/search/view_doc.asp?symbol=A/CONF.199/20\&Lang=E> accessed 2 October 2017.

66 See Provisional List of Delegations to the United Nations Conference on Sustainable Development Rio+20, <https://sustainabledevelopment.un.org/content/documents/792 7 draftlistofdelegationsuncsdrio20.10.pdf $>$. 
mentioned above that have shaped the development of international environmental law. ${ }^{67}$ The influence of the South is clear from its emphasis on eradicating poverty, which it considered as 'the greatest global challenge facing the world today and an indispensable requirement for sustainable development, ${ }^{\prime} 8$ and its multiple mention of developing countries.

\subsection{Sustainable Development Goals (2015)}

The Rio+20 (2012) Conference resolved 'to establish an Open Working Group to develop a set of sustainable development goals for consideration and appropriate action by the General Assembly', and provided the basis for the conceptualization of such goals. The mandate required that the Sustainable Development Goals (SDGs) 'should be coherent with and integrated into the UN development agenda beyond 2015' ${ }^{\prime 9}$ The 17 SDGs and their 169 associated Targets are set forth in the document Transforming our World: the 2030 Agenda for Sustainable Development. ${ }^{70}$ The Declaration contained within Transforming our World once again reflects the urgent needs of developing countries, with a heavy emphasis on the eradication of poverty. Notably, in 2016 the High Level Political Forum ${ }^{71}$ that reviews the implementation of the 2030 Agenda and the Goals focused on the commitment 'Ensuring that no one is left behind', and in 2017, on 'Eradicating poverty and promoting prosperity in a changing world. ${ }^{72}$

Although the main focus of this article is on the contribution of the developing countries to expanding field of international environmental law, it should be acknowledged that the judiciaries of the developing countries, particularly in Southeast and South Asia, have played a significant role in supporting, redefining and developing national environmental laws and policies which have impacted on, and on occasion have confirmed, the development of international

67 These are listed in Paragraphs 16, 17 and 18 in Section II Renewing Political Commitment, in the Annex to the Outcome Document of Rio+2o The Future We Want, <https://sustain abledevelopment.un.org/futurewewant.html $>$ accessed 2 October 2017.

68 Para 2; see also para 4.

69 Open Working Group proposal for Sustainable Development Goals <https://sustainable development.un.org/focussdgs.html> accessed 2 October 2017.

$70 \quad$ See $n 51$.

71 In 2016 the High Level Political Forum replaced the Commission on Sustainable Development that had been in place since the early 1990s.

72 See $<$ https://sustainabledevelopment.un.org/hlpf $>$ accessed 2 October 2017. 
environmental law. From the concept of 'intergenerational justice' upheld in Oposa v Factoran ${ }^{73}$ in the Philippines to carving out the 'right to environment' as being assumed in the constitutionally-proclaimed fundamental right to life by the Supreme Courts in India and Pakistan, mostly as public interest litigation or environmental public interest litigation, the judiciaries in the South have generally demonstrated vision and innovation in supporting the global goals of sustainable development. ${ }^{74}$

\section{$5 \quad$ Conclusion}

In advancing international environmental law, the lessons in the evolution of universal international law are crucial. Five decades ago, all rules of traditional international law were under serious stress. The newly emerging and independent states of Asia and Africa, supported by the developing world in South America, questioned the validity and legitimacy of these norms of international law, in the formulation of which the developing world had not participated. Most often, those norms served the interests of the developed Western

73 Oposa v Factoran Supreme Court of the Philippines, G.R. No. 101083 July 30, 1993.

74 The author has elsewhere documented the interaction of international environmental law norms and principles with the jurisprudence and active involvement of judiciaries in the developing countries. particularly in South Asia, in the field of environmental protection; see Parvez HASSAN, 'Environmental Rights as part of Fundamental Rights: The Leadership of the Judiciary in Pakistan', in A. POSTIGLIONE (ed), The Role of the Judiciary in the Implementation and Enforcement of Environment Law, 135-159 (Bruylant Bruxelles 2008); chapter on Pakistan (with Jawad HASSAN), in L. KOTZÉ and A. PATERSON (eds), The Role of the Judiciary in Environmental Governance: Comparative Perspectives, 381-409 (Wolters Kluwer 2009), 'Securing Environmental Rights through Public Interest Litigation in South Asia', in 22:3 Virginia Environmental Law Journal 216-236 (2004)); 'Changing Global Order: The Role of Pakistan's Courts and Tribunals in Environmental Protection' Environmental Policy and Law, 44/1-2; 'Environmental Jurisprudence from Pakistan: Some Lessons for the SAARC Region', 2012 Corporate Law Decisions, 24-49; 'The Greening of Judiciaries in South Asia', 2015 Pakistan Law Journal, 23-44; 'Public Trust Doctrine and Environmental Issues before the Supreme Court of Pakistan', 2012 Pakistan Law Journal, 44-64; 'Rule of Law and Access to Information, Public Participation in Decision-Making and Access to Justice in Environmental Matters in Pakistan', 2014 Pakistan Law Journal 425-440. See also Jona RAZZAQUE, Public Interest Environmental Litigation in India, Pakistan and Bangladesh (Kluwer 2004). 
nations, and were alien to the aspirations of the developing countries. They were therefore not acceptable to them. ${ }^{75}$

International law evolved in the post-colonial era with a new dynamism, both visionary and resilient, with a willingness to accept the viewpoint of new participants in the global process. Whether it was the international protection of human rights, or international law regarding the permanent sovereignty of nations over their natural wealth and resources, or the laws relating to diplomatic and consular immunities, or the law relating to the seas and oceans, or the law on treaties - each of these assimilated, to some extent, the interests of the developing countries.

In the field of human rights, for example, when the United Nations first internationalized the protection of human rights through the Universal Declaration of Human Rights in 1948, fewer than fifty states had voted for its adoption. The 1966 International Human Rights Covenants, namely the International Covenant on Civil and Political Rights and the International Covenant on Economic, Social and Cultural Rights, which concretized the declaratory content of the Universal Declaration into binding treaty obligations, were adopted 18 years later in 1966. There was much disappointment among international scholars with regard to the slowness with which the Covenants were finalized. But an important redemptive feature of this delay enabled the participation of an additional 6o new countries, most of them developing countries, in the formulation of these human rights norms. The Covenants, in the drafting of which more than 110 countries participated, certainly represent the commonality of interests of all countries, developing and developed.

The codification of international law by the participatory processes of the uN General Assembly and the International Law Commission in the past three decades has also enabled the Asian-African countries to redress the features of traditional international law that precluded universal application to diverse cultures.

The ultimate integrity of international law is the commonality and synthesis of the interests of all states, rich and poor, agricultural and industrial, and these were duly taken into account in the development of international environmental law. Although the developing countries did not have the opportunity to participate in the foundation of public international law up to

75 This section draws from the author's address, 'Moving Towards a Just International Environmental law', to the International Environmental Law Conference, The Hague (12-16 August 1991), reproduced in S. Bilderbeek (ed), Biodiversity and International Law, $7^{-2} 75$ (IOS 1992). 
the 2oth century, they have played and continue to play a critical role in the development of international environmental law through their participation in conferences, negotiation of treaties and soft law texts. Their participation adds immeasurable strength to the current state and future development of international environmental law.

Out of the continuing dialogue traced in this article, from the 1972 Stockholm Conference onwards, durable principles and concepts have emerged, such as inter-generational equity, intra-generational equity, polluter pays principle, principle of sustainable development, public participation, environmental impact assessment, principle of prevention, precautionary principle, principle of restitution/restoration of environment, principle of strict liability, public trust doctrine, and RRR (reduce, recycle, and reuse) in waste management.

This emerging global environmental order has, to an extent, developed a corpus of soft law and principles for national and international conduct that have impacted on humanity and Planet Earth. There have been attempts to transform these soft law principles into binding treaty obligations of states, as documented above, and some of them have become part of international customary law. The internationalization of the protection of human rights provides some comfort to the slow development of legally binding instruments. After all, it took 18 years to transform the declaratory content of the Universal Declaration of Human Rights in 1948 into binding commitments under the 1966 International Covenants on Civil and Political Rights and on Economic, Social and Cultural Rights. More of the soft law content of the Stockholm Principles on Human Environment (1972), World Charter of Nature (1982), Rio Declaration on Environment and Development (1992) and the Johannesburg Declaration on Sustainable Development (2002) may yet become binding. In an important initiative in 2017, the French Club des Juristes has developed a Global Pact for the Environment, supported by the French Government and the International Union for Conservation of Nature, among others. ${ }^{76}$ It is a measure of the robustness of the IUCN Draft International Covenant on Environment and Development that the sponsors of the Global Pact consulted the Covenant and involved the Covenant's principal architects in the drafting of the Pact.

${ }_{76}$ French Club des Juristes 'Global Pact on the Environment' World Commission on Environmental Law <https://www.iucn.org/news/world-commission-environmentallaw/201707/global-pact-environment-introduced-world-0> accessed ${ }_{15}$ October 2017. 